\title{
ENDOCARDITIS CAUSED BY A COPRINUS SPECIES: A FUNGUS OF THE TOADSTOOL GROUP
}

\author{
D. C. E. Speller* and A. G. MacIver \\ Department of Pathology, Radcliffe Infirmary, Oxford
}

Plates XXI-XXIV

FUNGAL endocarditis, which was once a rare disease, is being encountered with increasing frequency, particularly after cardiac surgery. A number of opportunistic pathogens, mainly Candida and Aspergillus species, have been responsible. We here report a case of endocarditis caused by the conidial stage of a Coprinus species, a basidiomycete.

\section{CLINICAL HISTORY}

The patient was a 53-yr-old man. A systolic murmur had been noted in 1939, but he had been passed A1 for military service, and had remained fit until 1962, when he had bacterial endocarditis caused by a viridans streptococcus, and was found to have mild mitral incompetence. The infection was successfully treated with penicillin and streptomycin, to one of which drugs he had an allergic reaction with a rash and eosinophilia; during the next few years he developed increasing mitral incompetence with left ventricular failure. Cardiac catheterisation and aortic angiography in April 1968 demonstrated pure mitral incompetence and a normal aortic valve.

In August 1968 his mitral valve was replaced by a Beale prosthesis. At operation, both cusps of the mitral valve were seen to be enlarged and distorted, with invagination of the floppy anterior cusp into the left atrium. Post-operatively he had a short episode of spiking fever and jaundice, but eight blood cultures yielded no significant growth (see below). He was given a course of chloramphenicol at this time, and other antibiotics were administered for short periods.

After this he made good progress, and remained well for $6 \mathrm{mth}$, apart from occasional chest pain and an episode $4 \mathrm{mth}$ after the operation when he collapsed in the street and was briefly admitted to hospital. No cause was found for his collapse, which was tentatively attributed to a transient dysrhythmia. Three blood specimens collected during his brief stay in hospital on that occasion were sterile.

In April 1969, however, he was admitted again, after 3 wk of increasing breathlessness and chest pain, with fever and splenomegaly, signs of congestive failure and, for the first time, aortic incompetence. Endocarditis was diagnosed, but no agent could be isolated; six blood cultures yielded no significant growth (see below). No antibodies to Coxiella burnetii could be detected.

He was treated with cephaloridine and sodium fusidate, and later with cephaloridine and lincomycin, with no improvement. His condition deteriorated, with episodes of acute left ventricular failure and a probable peripheral embolus, and it was decided to replace his aortic valve with a Starr-Edwards prosthesis as an emergency procedure. This was accomplished, but the patient died while still undergoing cardiopulmonary bypass.

\section{Pathology}

The mitral valve removed at the first operation had normal architecture and consisted of connective tissue with no evidence of fibrous scarring or other pathological change associated with rheumatic carditis or previous infective endocarditis.

Received 6 Aug. 1970; accepted 17 Sept. 1970.

* Present address: Department of Bacteriology, University of Bristol.

J. MED .MICROBIOL.-VOL. 4 (1971) 
The aortic valve resected at the final operation had cusps that were almost completely destroyed and replaced by friable vegetations; sections of these showed much septate mycelium in association with an acute inflammatory reaction (fig. 1). A vegetation from the aortic wall above the valve showed a similar microscopic picture.

Post mortem the valve prostheses were intact. The left ventricle was hypertrophied to $2.5 \mathrm{~cm}$ in thickness and the myocardium contained some paler areas within it. No peripheral infarcts were found.

Histologically the myocardium showed both diffuse and focal fibrosis. Numerous small areas of inflammation were seen, particularly in relation to small blood vessels, with focal myocardial necrosis. Some multinucleate giant cells were present, as well as subacute inflammatory cells, principally lymphocytes and polymorphonuclear cells, many of which were eosinophil in type. Some PAS-positive material, resembling degenerate fungal elements, was seen in the cytoplasm of some of the giant cells.

In the lungs a few fungal elements were present in the bronchi, but neither these nor the alveoli showed any inflammatory process. Some hilar lymph-nodes contained granulomata with multinucleate giant cells.

Some of the renal tubules contained neutrophil polymorphs, but other renal stigmata of infective endocarditis were absent. An increased number of chronic inflammatory cells was seen in the portal tracts of the liver, but no giant cells or fungal elements were found there.

\section{MICROBIOLOGY}

Blood specimens for culture during life were taken into 5 per cent. sodium polyanethol sulphonate (Liquoid) broth. From these, pour plates were prepared for incubation aerobically and anaerobically, with 2 per cent. and 5 per cent. of carbon dioxide respectively. Three broth cultures, two in nutrient broth and one in 0.1 per cent. thioglycollate broth, were also made from each specimen by the addition of 1-3 ml of blood to $40 \mathrm{ml}$ of medium.

During the patient's 1962 admission to hospital, a viridans streptococcus was grown from all cultures from three separate blood specimens. Between the time of his mitral valve replacement in 1968 and his death 9 mth later, 17 blood specimens were cultured. Of these, nine were sterile, and eight yielded coagulase-negative staphylococci or flavobacteria from single broth cultures. These latter isolates were of varying antibiotic sensitivity; no consistent growth was obtained and no agglutinins to these organisms could be detected in the patient's serum.

From several pieces of the vegetations on the aortic valve removed at operation a fungus was grown on blood agar and on glucose-peptone agar in $48 \mathrm{hr}$ at $37^{\circ} \mathrm{C}$. There was no bacterial growth. The fungus grew well on glucose-peptone agar at $29^{\circ} \mathrm{C}$ and $37^{\circ} \mathrm{C}$, producing a dense white felt of aerial mycelium which eventually became heaped and wrinkled (fig. 2 ). The reverse of the colony was dull-yellow to flesh-coloured. Few spores were produced on this medium, but after about 2 mth large numbers of dark brown, irregularly rounded to ovoid sclerotia appeared (fig. 3); they were filled with closely packed colourless cells with extremely thick walls resembling the " hülle" cells of some Aspergillus species (fig. 4).

On many media other than glucose-peptone agar, aerial mycelium was sparse, but abundant sporing took place. Further observations were made on lactophenol cotton blue mounts of cultures on potato-sucrose agar. The cylindrical conidia were borne on short, stout, branched conidiophores arising laterally from trailing hyphae. Both conidia and conidiophores were colourless. The conidia were held in clusters at the tips of the conidiophores by drops of viscous liquid (fig. 5). The tips of the conidiophore branches were somewhat enlarged and gave rise to 2-5 finger-like cells of the same diameter as the spores but approximately twice their length (fig. 6).

After unsuccessful attempts by various authorities to identify the fungus, it was sent to Dr G. A. de Vries of the Centraalbureau voor Schimmelcultures, Holland, who identified it as the conidial stage of a Coprinus species, on the basis of its morphological similarity to that of C. lagopus (Brefeld, 1877; Brodie, 1931).

Blood artificially seeded with a suspension of the organism in the laboratory was 
submitted to the routine blood culture method and obvious growth was obtained on the aerobically incubated pour plate and in the aerobic broth cultures at $48 \mathrm{hr}$.

The fungus was tested for sensitivity to chemotherapeutic agents, by an incorporation plate technique in which Yeast Morphology Agar (Bacto) was seeded with a saline suspension of ground-up fungal colonies. Growth was inhibited by amphotericin B at a concentration of $0.25 \mu \mathrm{g}$ per $\mathrm{ml}$, but was unaffected by 5 -fluorocytosine in concentrations up to $250 \mu \mathrm{g}$ per $\mathrm{ml}$.

\section{Discussion}

Merchant et al. (1958) reviewed 34 cases of fungal endocarditis, of which 18 occurred as part of an infection with a recognised fungal pathogen, including Histoplasma capsulatum, Blastomyces dermatitidis, Coccidioides immitis and Cryptococcus neoformans. A further 11 were due to Candida species, and the predominance of Candida is confirmed by subsequent reports (Andriole et al., 1962; McConnell and Roberts, 1967). The remaining five cases reviewed by Merchant et al. were of other opportunist fungal pathogens: four Aspergillus strains and one Mucor. Many other reports of Aspergillus endocarditis have since appeared in the literature; of 20 such cases since 1963, 18 followed cardiac surgery (Luke, Bolande and Gross, 1963; Newman and Cordell, 1964; Amoury, Bowman and Malm, 1966; Stein, Harken and Dexter, 1966; Darrell, 1967; Morea et al,,1967; Caplan et al., 1968; Doughten and Pearson, 1968; Khan, Kane and Dean, 1968; Mahvi et al., 1968; Mershon, Samuelson and Layman, 1968; Hairston and Lee, 1969; Jones, Meshel and Rubin, 1969; Royal Postgraduate Medical School, 1969). In some, no culture was achieved, and identification of the infecting agent was made on morphological appearances of mycelium in the vegetations, an unsatisfactory method that is very subject to error. Cavallo, Lichewitz and Arvai (1968) reported infection of a Starr-Edwards prosthesis by a fungus thought to be a Penicillium or Hormodendrum species, but again the identification was based on the morphology of the fungus in histological sections. Uys et al. (1963) reported a case of endocarditis caused by Paecilomyces varioti, a widely distributed saprophyte, which was cultured from blood and from thrombus attached to the valve.

Basidiomycetes have very rarely been implicated in human or animal disease, presumably mainly because of their inability to grow at $37^{\circ} \mathrm{C}$. Human infection by a Coprinus species has not previously been reported, but this genus is singled out by Cooney and Emerson (1964) in their discussion of thermophilic fungi as the only genus in the Basidiomycetes known to contain thermotolerant members. The genus Coprinus contains both the "ink cap " toadstools and species with smaller, non-deliquescent fruit bodies. A number of coprini are coprophagous, but this is not a universal character; some may grow on decaying vegetation, and species have been described growing on plaster (Orton, 1957). These fungi have a monokaryotic conidial form that rarely produces fruit bodies, and this is the form in which the present strain was isolated.

This fungus is clearly not identical with C. lagopus (Brefeld, 1877), for it shows differences in the conidiophores and possesses sclerotia. A culture of the thermotolerant species, C. delicatulus (Apinis, 1965), that was obtained from the Commonwealth Mycological Institute, bore sclerotia, but differed from the present strain in the structure of both sclerotia and conidial apparatus. It does appear, however, that the present strain is more closely related to the non-deliquescent $C$. delicatulus type than to $C$. lagopus.

The fungal mycelium could have developed from basidiospores from the toadstool stage, which may be airborne; on the other hand, it may have arisen from conidia, which are encased in drops of slime and are presumably disseminated by adhering to objects that come into contact with them. Brodie (1931) showed that conidia of $C$. lagopus could be transferred by flies, both by adhering to their feet and by being eaten and passed in excreta without death of the conidia. It is thus clear that this fungus could be found in dust and on human skin and it is likely that implantation of it on the aortic valve of our patient occurred at the time of operation. There is evidence to suggest that when candida endocarditis follows cardiac surgery, infection has occurred at the time of operation or soon after (Cooper et al., 1961; Murray, Buckley and Turner, 1969) although there may be a 
COPRINUS ENDOCARDI'TIS

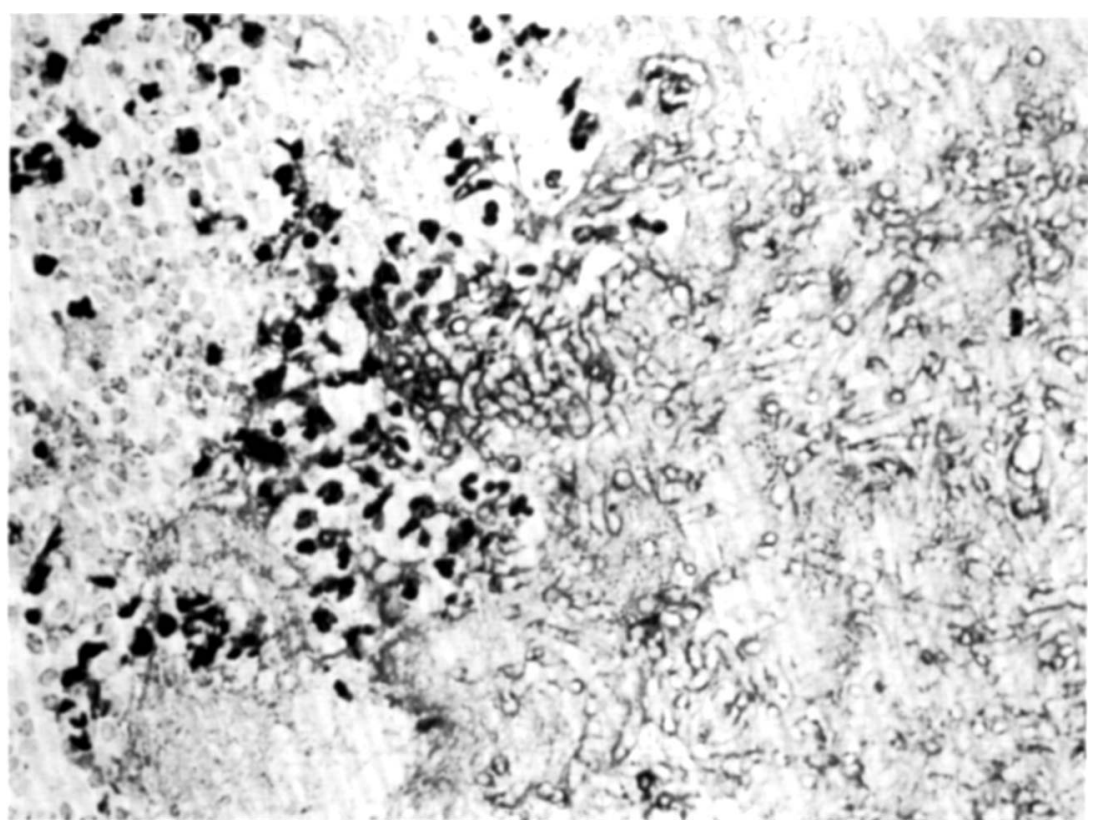

FIG. 1.-Section of aortic valve, showing inflammatory cells and numerous fungal hyphae. PAS stain. $\times c .350$.

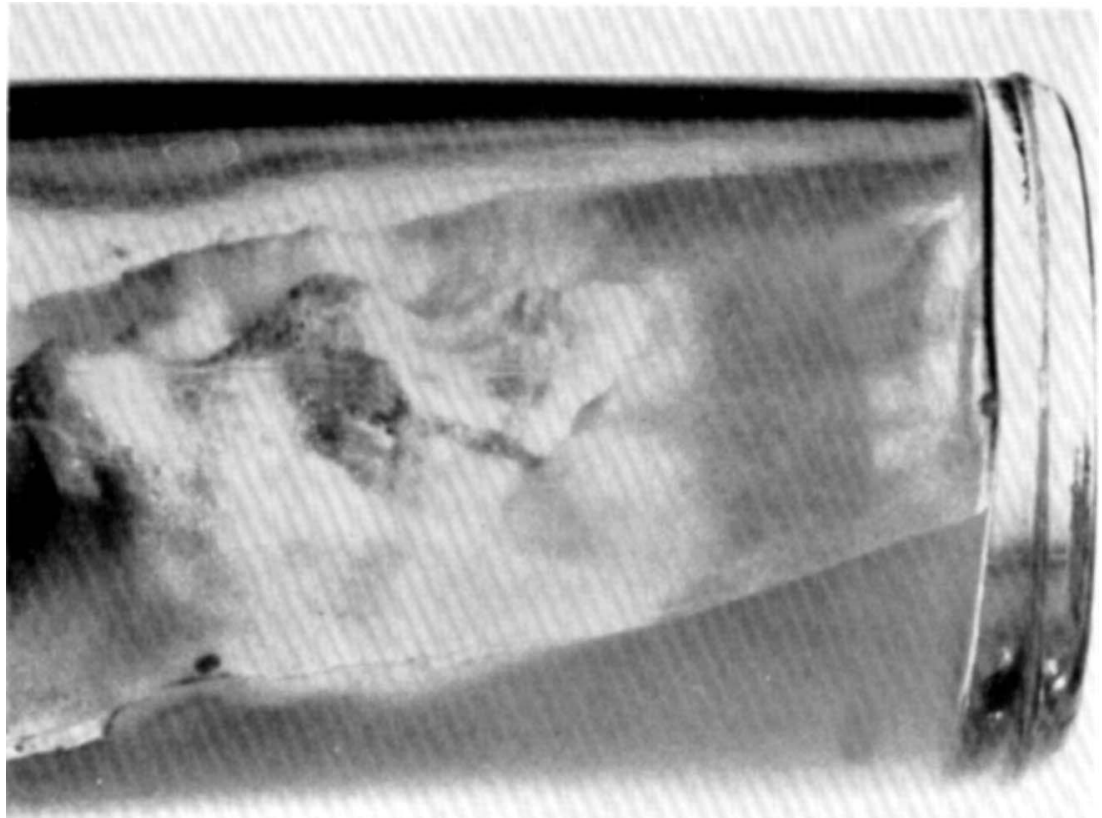

FIG. 2.-Coprinus sp. isolated from aortic valve. Three-month-old culture, at room temperature, on glucose-peptone agar. $\times c .6$. 


\section{COPRINUS ENDOCARDITIS}

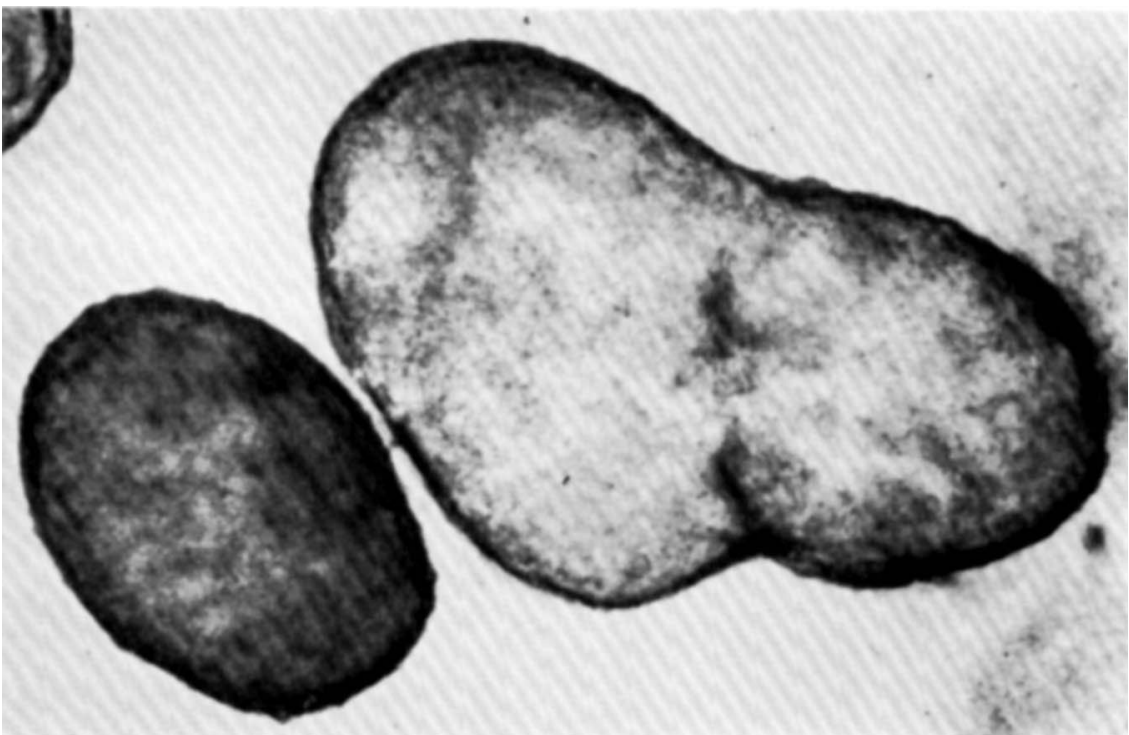

FiG. 3.-Sclerotia. Lactophenoi cotton blue mount. $\times c .200$.

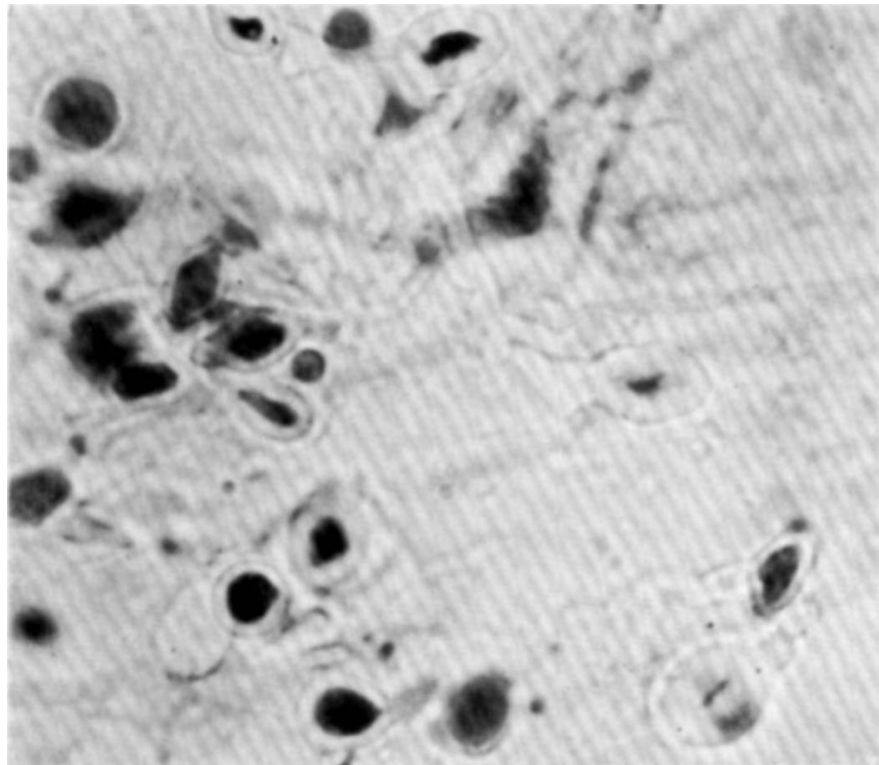

FIG. 4.-Contents of sclerotia; note the excessively thick-walled cells. Lactophenol cotton blue mount. Phase-contrast microscopy. $\times c .600$. 
COPRINUS ENDOCARDITIS

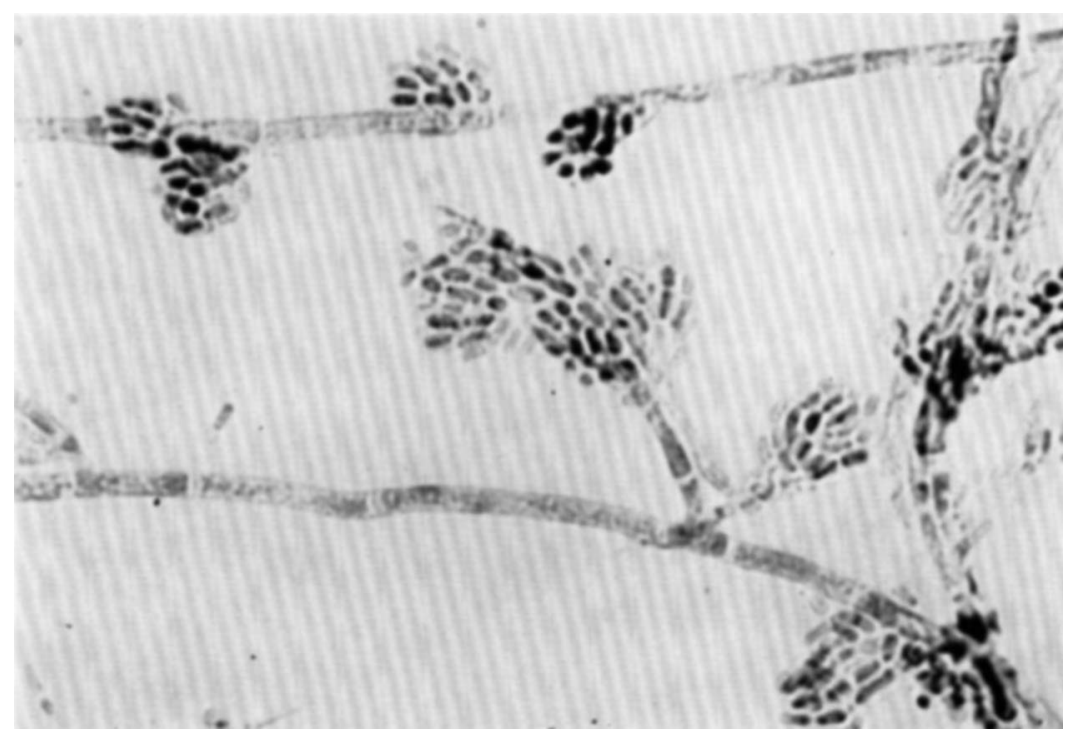

FIG. 5.-Conidiophores. Lactophenol cotton blue mount. $\times c .600$.

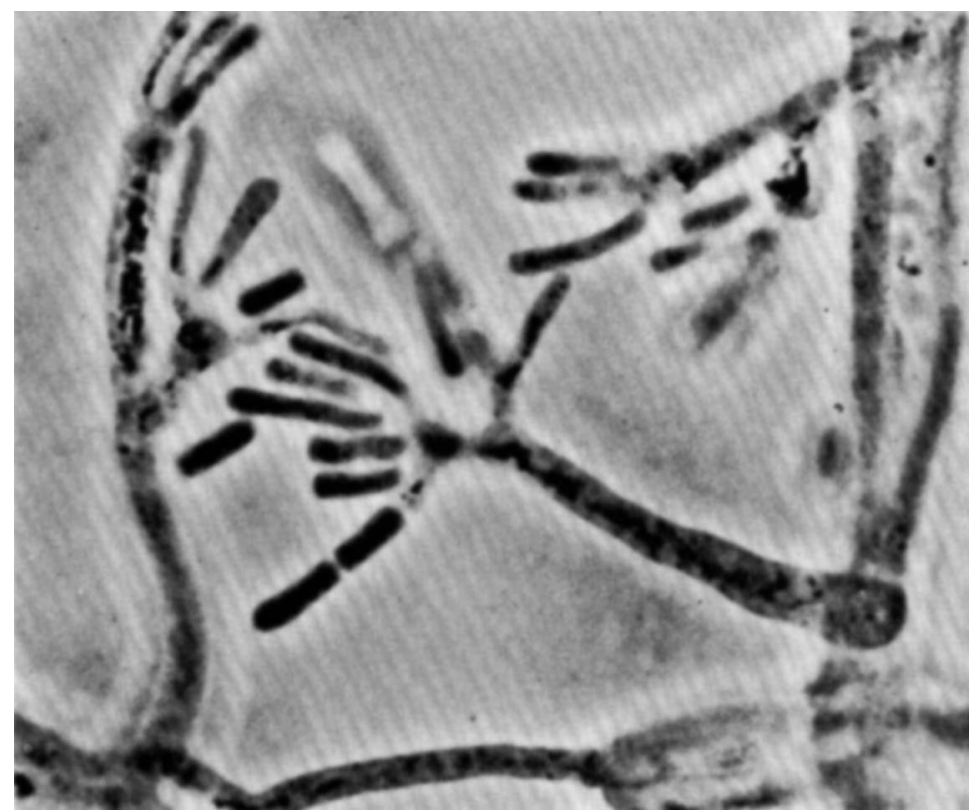

FIG. 6.-Detail of conidiophore. showing finger-like processes and conidia. Lactophenol cotton blue mount. $\times$ c. 2000. 


\section{COPRINUS ENDOCARDITIS}

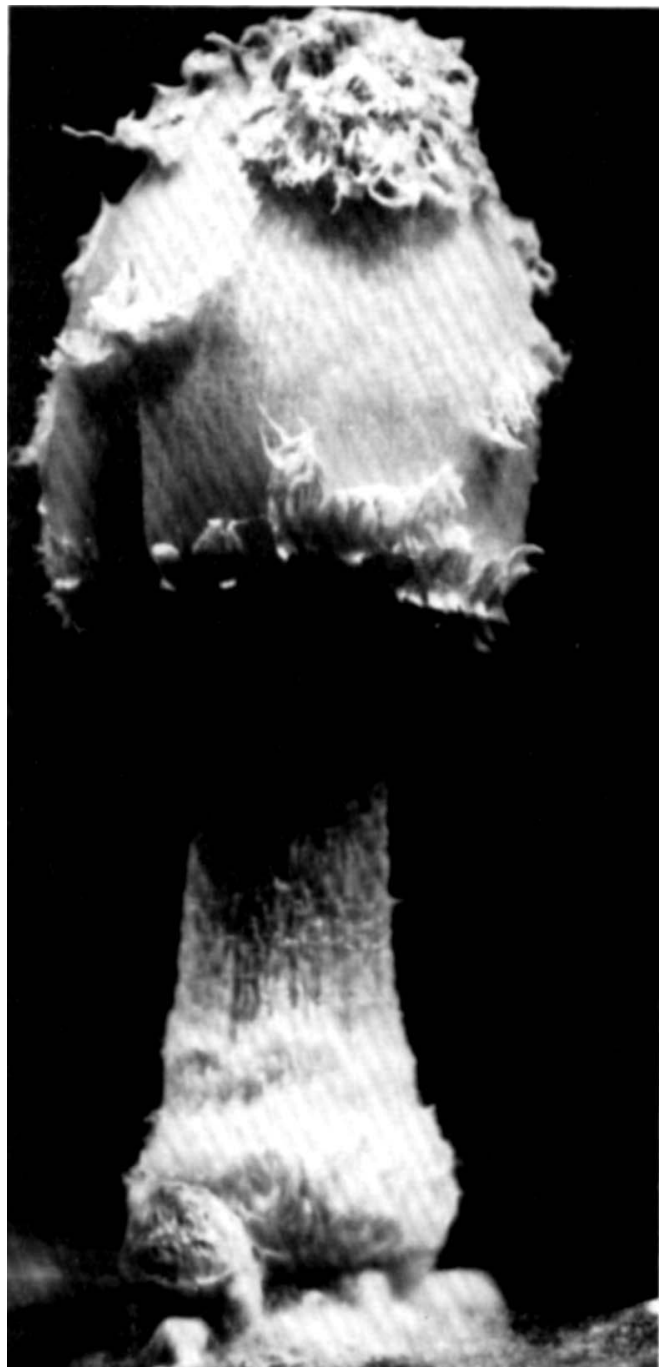

FIG. 7.-Fruiting body developed from dikaryon obtained by fusion of the pathogenic Coprinus and Coprinus cinereus. $\times$ c.12. (See Addendum). 
considerable period of good health before clinical signs develop (Sanger et al., 1962). It is also possible that fungal endocarditis arises in the post-operative period by blood-borne infection from a focus in the respiratory or alimentary tracts. Fungal elements were seen in post-mortem sections of the bronchi of our patient, but it is probable that these represented Candida rather than Coprinus, for the finding of Candida is extremely common in patients who have received antibiotics, and colonisation of the bronchi with basidiomycetes has not been reported and is most unlikely.

The fungus was not isolated from the blood of our patient, although six specimens were examined during his last period in hospital by a technique demonstrably able to grow the organism from blood in the laboratory. Aspergillus species have been isolated from blood cultures on occasions (Newman and Cordell; Stein et al.), but usually blood cultures are negative even when special measures are taken to isolate fungi. It may be that fungaemia does not occur consistently in these patients, and that dissemination takes place only when pieces of vegetation break off as micro-emboli, as seen in the coronary circulation of our patient; but it is also possible that conditions in the broth cultures are not suitable for growth of the fungus from a small number of elements in the blood. Candida species, on the other hand, are readily isolated from blood by customary techniques, though the use of glucose-peptone agar to make pour-plates may increase the speed and consistency of the isolation (personal observation).

There are no reports of successful chemotherapy of fungal endocarditis other than rare cures of candida infections with amphotericin B (see Kay et al., 1968). Valve replacement, possibly in association with treatment with amphotericin, to which the Coprinus strain was moderately sensitive, offers the best chance of recovery (Kay et al.).

\section{SUMMARY}

A species of Coprinus, a widely distributed genus of the toadstool group of fungi, caused endocarditis of the normal aortic valve of a patient who had undergone mitral valve replacement. Human infection by this genus has not hitherto been reported.

We are grateful to Dr G. de J. Lee for permission to publish this case, to Dr M. S. Dunnill for the post-mortem findings, to Mr C. C. Jeal and Mr D. T. J. Luckett for the photomicrographs, to Miss Phyllis Stockdale for the culture of C. delicatulus, and to Dr Mary P. English and Dr G. A. de Vries for their help with the investigation and description of the fungus.

\section{REFERENCES}

Amoury, R. A., Bowman, F. O., JR, AND Malm, J. R. 1966. Endocarditis associated with intracardiac prostheses. Diagnosis, management, and prophylaxis. J. Thorac. Cardiovasc. Surg., 51, 36.

Andriole, V. T., Kravetz, H. M., Roberts, W. C., AND Utz, J. P. 1962. Candida endocarditis. Clinical and pathologic studies. Amer. J. Med., 32, 251.

ApINIS, A. E. 1965. A new thermophilous Coprinus species from coastal grasslands. Trans. Br. Mycol. Soc., 48, 653.

BREFELD, O. 1877. Botanische Untersuchungen über Schimmelpilze, III, Leipzig, p. 98.

Brodie, H. J. 1931. The oidia of Coprinus lagopus and their relation with insects. Ann. Bot., 45, 315.

Caplan, H. I., Frisch, E., Houghton, J. D., Climo, M. S., and Natsios, G. A. 1968. Aspergillus fumigatus endocarditis. Ann. Intern. Med., 68, 378.

Cavallo, T., Lichewitz, B., AND Arvai, K. 1968. Opportunistic fungal endocarditis following aortic valve replacement. A case report. Revta Inst. Med. trop. S. Paulo, 10, 326.

Cooney, D. G., and Emerson, R. 1964. Thermophilic fungi, San Francisco, p. 110.

Cooper, T., Morrow, A. G., Roberts, W. C., and Herman, L. G. 1961. Postoperative endocarditis due to Candida. Clinical observations and the experimental production of the lesion. Surgery, St Louis, 50, 341. 
DARrell, R. W. 1967. Endogenous aspergillus uveitis following heart surgery. Archs Ophthal., 78, 354.

Doughten, R. M., and Pearson, H. A. 1968. Disseminated intravascular coagulation associated with Aspergillus endocarditis. J. Pediat., 73, 576.

Hairston, P., AND LeE, W. H., JR 1969. Mycotic (fungal) endocarditis after cardiovascular surgery. Amer. Surg., 35, 135.

Jones, Thelma, Meshel, L., AND Rubin, I. L. 1969. Aspergillus endocarditis superimposed on aortic valve prosthesis. N.Y. St. J. Med., 69, 1923.

Kay, J. H., Bernstein, S., Tsuji, H. K., Redington, J. V., Milgram, Millie, and Brem, T. 1968. Surgical treatment of candida endocarditis. J. Amer. Med. Assoc., 203, 621.

Khan, T. H., Kane, E. G., and Dean, D. C. 1968. Aspergillus endocarditis of mitral prosthesis. Amer. J. Cardiol., 22, 277.

Luke, J. L., Bolande, R. P., AND Gross, S. 1963. Generalized aspergillosis and aspergillus endocarditis in infancy. Pediatrics, Springfield, 31, 115.

McConnell, E. M., AND Roberts, C. 1967. Pathological findings in three cases of fungal endocarditis complicating open-heart surgery. J. Clin. Path., 20, 555.

Mahvi, T. A., Webb, Hazel M., Dixon, C. D., and Boone, J. A. 1968. Systemic aspergillosis caused by Aspergillus niger after open-heart surgery. J. Amer. Med. Assoc., $203,520$.

Merchant, R. K., Louria, D. B., Geisler, P. H., Edgcomb, J. H., and Utz, J. P. 1958. Fungal endocarditis: review of the literature and report of three cases. Ann. Intern. Med., 48, 242.

Mershon, J. C., Samuelson, D. R., and Layman, T. E. 1968. Left ventricular " fibrous body" aneurysm caused by aspergillus endocarditis. Amer. J. Cardiol., 22, 281.

Morea, M., Girelli, L., Benintendi, V., and Scaravilli, F. 1967. Endocardite aspergillare a seguito di intervento cardiochirurgico. Chir. ital., 19, Suppl. 2, p. 173.

Murray, I. G., BuCKLey, Helen R., AND Turner, G. C. 1969. Serological evidence of candida infection after open-heart surgery. J. Med. Microbiol., 2, 463.

Newman, W. H., aNd CoRdell, A. R. 1964 . Aspergillus endocarditis after open-heart surgery. Report of a case and review of literature. J. Thorac. Cardiovasc. Surg., 48,652 .

Orton, P. D. 1957. Notes on British agarics 1-5 (observations on the genus Coprinus). Trans. Br. Mycol. Soc., 40, 263.

Royal Postgraduate Medical School Clinico-Pathological Conference 1969. A case of fungal endocarditis. Br. Med. J., 3, 765.

SAnger, P. W., TAylor, F. H., Robicsek, F., Germuth, F., Senterfit, L., AND McKinnon, G. 1962. Candida infection as a complication of heart surgery. J. Amer. Med. Assoc., $181,88$.

Stein, P. D., Harken, D. E., AND Dexter, L. 1966. The nature and prevention of prosthetic valve endocarditis. Amer. Heart J., 71, 393.

Uys, C. J., Don, Phyllis A., Schrire, V., And Barnard, C. N. 1963. Endocarditis following cardiac surgery due to the fungus Paecilomyces. S. Afr. Med. J., 37, 1276.

\section{Addendum}

Since this paper was submitted Dr R. F. O. Kemp of Edinburgh University has shown by his hyphal-oidial fusion technique (Kemp, 1970) that the fungus forms a dikaryotic mycelium, with clamp connexions and fruit bodies, with the isolate of $C$. delicatulus mentioned above, and with the common species $C$. cinereus (fig. 7), of which $C$. delicatulus is probably merely a variety. Our fungus is therefore probably Coprinus cinereus.

\section{REFERENCE}

KeMP, R. F. O. 1970. Interspecific sterility in Coprinus bisporus, $C$. congregatus and other basidiomycetes. Trans. Br. Mycol. Soc., 54, 488. 